DOI: http://doi.org/10.4038/agrieast.v12i2.57

\title{
Effect of Homemade Effective Microorganisms on the Growth and Yield of Chilli (Capsicum annuum) MI-2
}

\author{
Kodippili, K.P.A.N* and Nimalan, J
}

Department of Bio-Science, Faculty of Applied Science, Vavuniya Campus of the University of Jaffna

\begin{abstract}
Using Effective Microorganisms (EM) is an ecofriendly approach to reduce the application of synthetic fertilizers in agriculture. The study was conducted to evaluate the efficacy of homemade EM along with compost on growth, yield parameters of chilli (Capsicum annuum) at Hunumulla agricultural farm, Gampaha District. Field experiment was carried out in a Randomized Complete Block Design with three treatments and each treatment had three replicates. The treatments were control (T1), compost (T2) and EM + compost (T3). EM solution was prepared by keeping cooked rice balls in a cool dark place for the enrichment of microbial growth and filled with sugarcane molasses for the fermentation. ANOVA and Duncan's multiple range analysis were used to analyze the data using SPSS 22.The results showed that $E M+$ compost treated crops showed significantly $(P<0.05)$ highest plant height $(29.76 \mathrm{~cm})$, number of leaves per plant (176.40), number of branches per plant (44.67), number of flowers per plant (15.47) and number of chilli pods per plant (10.60), but there were no significant differences observed between the EM + compost and compost $(P>0.05)$ in pod length, pod width and the weight of total chilli pods per crop. The present study concluded that growth and yield of the chilli crops were increased by the application of EM with compost compared to the application of compost only. EM with compost is a potential biofertilizer for encouraging organic farming.
\end{abstract}

Keywords: Capsicum annum, Compost, Effective Microorganisms.

\section{Introduction}

The world population increased geometrically but the production of food has not been increased such as a manner to full fill the requirements for feeding the world population, which lead to greater pressure on adequate food supply. The priorities should be given to increase the agriculture production to meet food requirement for the growing population. Excessive use of inorganic fertilizers leads in indirect side effects on environment as well as health effects in human. These chemicals produce a potential risk to humans and other life forms and unwanted side effects to the environment (Igbedioh, 1991).

Organic agriculture is one of the alternative ecofriendly approaches that prevent the excessive use of agrochemicals and enhance the quality of degraded environments. Crop production in traditional organic farming system generally adopted with the application of agricultural wastes and biofertilizers. Traditional organic farming system may not provide required quantities of food. One of the ways to improve traditional organic farming is that adaptation of ecofriendly biotechnological methods which improve the quality and quantity of food production in sustainable manner (Sangakkara, 1998)

Smallholder farming systems in the developing world and home gardeners worldwide use organic amendments to improve soil fertility and productivity (Pendleton and Lawson, 1989). Effective Microorganisms are the group of heterogeneous microorganisms which include mainly lactic acid Bacteria,
Corresponding author: kjgowri@vau.jfn.ac.lk Received: 18.07.2018 https:/ / orcid.org/0000-0002-6209-073X Accepted: 09.08.2018 
photosynthetic Bacteria, Actinomycetes, Fermenting fungi and Yeast (Higa and Kanal, 1998 and Takash et al., 1999).

Generally, EM solution is commercially available in the liquid form and it is used with compost. Kyusei nature farming is a system of farming that seeks to avoid the use of chemical fertilizer and pesticides. Lanka Sekai Kyusei Foundation instructed farmers to prepare homemade EM solution to maximize the use of on-farm resources and minimize the use of purchased offfarm inputs to conserve energy and reduce production costs, but still the studies related to evaluate the efficacy of homemade EM was not conducted.

Therefore, this study was conducted to evaluate the efficacy of homemade EM with compost on the growth and yield parameters of chilli in order to ensure sustainable application of homemade EM in organic farming.

\section{Materials and Methods}

\section{Experimental location}

The experiment was conducted at Hunumulla agricultural farm, Gampaha District, Sri Lanka. The district is located in mid country within the wet zone in Western Province of Sri Lanka.

\section{Method for the Preparation of EM + compost (EM Bokashi)}

For the preparation of EM Bokashi, 3 steps including preparation of homemade Effective Microorganisms, preparation of compost and preparation of EM + compost (EM Bokashi) were adopted according to the instruction given orally by Mr. Kingsley Kariyawasam, Vice president at Lanka Sekai Kyusei Foundation.

\section{Preparation of homemade Effective Microorganisms}

Rice balls were prepared with cooked rice (100 g) and they were covered with dried leaves and kept in cool dark place in the soil for 10 days for the enrichment of microorganisms. After 10 days the rice balls enriched with the microbial growth were placed in a container and the container was filled with sugarcane molasses up to the level of one inch distance below the mouth of the container. It was tightly packed to maintain an anaerobic condition and kept for about three weeks for the fermentation.

\section{Preparation of compost}

The compost was prepared by mixing rice powder $(500 \mathrm{~g})$, chopped gliricidia leaves $(2 \mathrm{~kg})$, goat manure $(2 \mathrm{~kg})$, eppawala rock phosphate (100 g) and ash (100 g) and kept for 21 days by sprinkling water over the pile regularly to ensure all the material is moist but not wet.

\section{Preparation of EM+ compost (EM Bokashi)}

EM Bokashi was prepared according to the method followed by Lanka Sekai Kyusei Foundation. The prepared EM solution (25 $\mathrm{ml})$ was diluted with water $(1: 100)$ before mixing with the compost mixture. The diluted EM solution $(2500 \mathrm{ml})$ was inoculated with compost mixture $(4.7 \mathrm{~kg})$ and fermented anaerobically at room temperature $\left(2{ }^{\circ} \mathrm{C}\right)$ about 21 days to prepare EM + compost (EM Bokashi). The $\mathrm{EM}+$ compost mixture was allowed for decomposing and fermenting by effective microorganisms which were included in the homemade EM solution during this period.

The cultivar MI-2 of chilli was used in this study. Nursery was prepared three weeks before transplanting the seedlings on the land. Fermented $\mathrm{EM}+$ compost $\left(500 \mathrm{~g} / 2.52 \mathrm{~m}^{2}\right)$ and the compost without EM $\left(500 \mathrm{~g} / 2.52 \mathrm{~m}^{2}\right)$ were applied to the plot before planting the seedlings in the field. Control plot was allowed without application of EM or compost. 


\section{Experimental design}

The experiment was conducted in Randomized Complete Block Design (RCBD (Fig.3) with three treatments such as T1 (control); T2 (compost); T3 (EM + compost). Block was designed by considering fertility gradient. Each replicate (plot) contained 10 plants and each treatment contained 30 plants. There were nine plots with size $2.4 \mathrm{~m} \times 1.05 \mathrm{~m}$ and each plot had two rows with $45 \mathrm{~cm}$ space. Three weeks old uniform seedlings were selected for transplanting in experimental plots and planted with $45 \mathrm{~cm}$ spacing in plot.

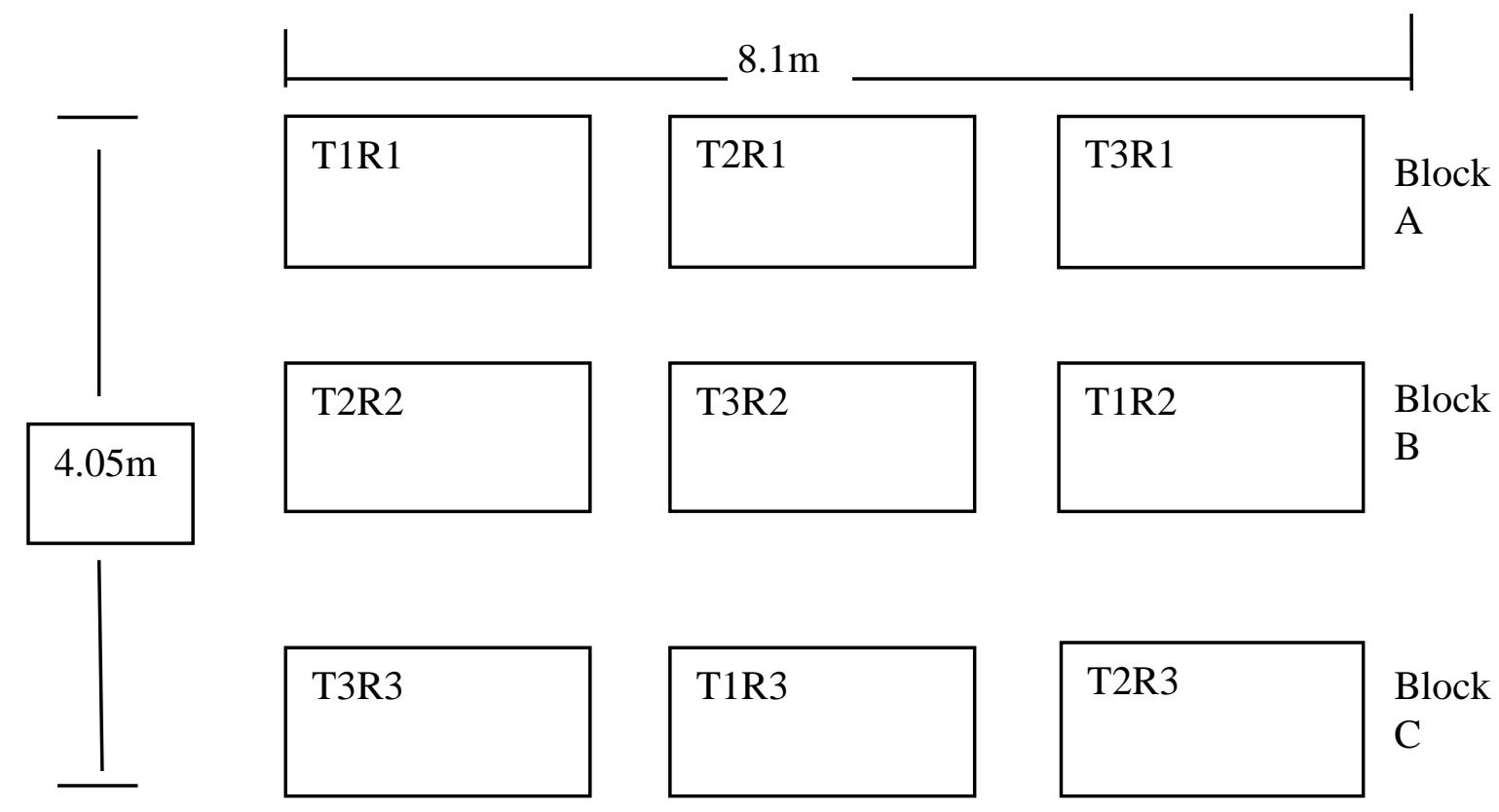

Fig.1: A layout for Experimental design (RCBD)

\section{Sample collection}

Chilli plants $(n=5)$ were randomly selected in each plot and mean was determined for each parameter. Nondestructive sampling method was adopted for the observations. Plant height, number of leaves per plant and, number of branches per plant were measured at 7 days interval from 28 to 63 days of planting in the field. Number of flowers was counted after the 6 weeks of transplanting while number of pods per plant length, and width of the chili pods and weight of total chilli pods per crop were measured at harvesting during 63 days of transplanting.

\section{Data analysis}

Means with standard deviation for all numerical data were calculated by using SPSS Statistics 22 software. ANOVA analyses were done at $\mathrm{a}=0.05$ significant level. Mean comparisons were done through Duncan's Multiple Range Test (DMRT) in SPSS software to compare the efficacy of each treatment on growth and yield parameters. 


\section{Result and Discussion}

\section{Effect of homemade EM on growth parameters}

\section{Height of Chilli crops}

The table 1 shows the height of chilli crop for different treatment.

Overall the results showed there was a significant difference between heights of the chilli crop for different treatments. $(\mathrm{P}=0.0000$ at $95 \% \mathrm{CI})$. The maximum growth height was observed in EM + compost treated crops at 63rd day after planting during the study period (Table 1). Arshad and Frankenberger reviewed that EM inoculation increased the value of plant growth and fruit yield parameters due to the microorganisms in EM change the properties of the organic materials for facilitate absorption and some microorganisms produce plant growth regulators which increase the growth and flowering capacity.

\section{Number of leaves per plant}

The Fig. 2 explained the increasing number of leaves for all treatments with the time. At $28^{\text {th }}$ day, number of leaves per plant of the crops was not significantly different from each treatment and control. In 49 day, number of leaves per plant was significantly higher in EM + compost treated crops compared to other treatments. In 63 $3^{\text {rd }}$ day, significantly maximum number of leaves per plant was observed in EM+ compost compared to other treatment.

Increase in leaf number is commonly found in plant with adequate amount of nutrients availability in soil and leads to increase the amount of photosynthetic activity. EM increase plant growth by increasing the rate of organic matter mineralization which results in an increase in plantavailable nutrients (Asia-Pacific Natural Agriculture,

1995).

Table 1. Height of chilli crops

\begin{tabular}{|c|c|c|c|c|c|c|}
\hline \multirow{2}{*}{ Treatment } & \multicolumn{6}{|c|}{ Height of chilli crops $(\mathrm{cm}) \pm$ SD } \\
\hline & 28th day & $\begin{array}{l}\text { 35th } \\
\text { Day }\end{array}$ & $\begin{array}{l}\text { 42th } \\
\text { Day }\end{array}$ & $\begin{array}{l}\text { 49th } \\
\text { Day }\end{array}$ & $\begin{array}{l}56 \text { th } \\
\text { day }\end{array}$ & $\begin{array}{l}\text { 63rd } \\
\text { day }\end{array}$ \\
\hline $\begin{array}{l}\text { EM+ } \\
\text { compost }\end{array}$ & $\begin{array}{c}11.55 \\
\pm \\
1.73^{a}\end{array}$ & $\begin{array}{c}12.91 \\
\pm \\
1.76^{\mathrm{a}}\end{array}$ & $\begin{array}{c}15.77 \\
\pm \\
1.96^{\mathrm{a}}\end{array}$ & $\begin{array}{c}20.41 \\
\pm \\
4.1^{\mathrm{a}}\end{array}$ & $\begin{array}{c}24.77 \\
\pm \\
3.98^{a}\end{array}$ & $\begin{array}{c}29.76 \\
\pm \\
3.43^{\mathrm{a}}\end{array}$ \\
\hline Compost & $\begin{array}{c}11.21 \\
\pm \\
1.61^{\mathrm{a}}\end{array}$ & $\begin{array}{c}12.23 \\
\pm \\
2.03^{\mathrm{ab}}\end{array}$ & $\begin{array}{c}14.54 \\
\pm \\
1.59 \mathrm{a}\end{array}$ & $\begin{array}{c}16.99 \\
\pm \\
2.79 \mathrm{~b}\end{array}$ & $\begin{array}{c}20.60 \\
\pm \\
3.85^{b}\end{array}$ & $\begin{array}{c}25.06 \\
\pm \\
4.39 \mathrm{~b}\end{array}$ \\
\hline Control & $\begin{array}{c}10.13 \\
\pm \\
2.19^{a}\end{array}$ & $\begin{array}{c}11.17 \\
\pm \\
1.38^{\mathrm{b}}\end{array}$ & $\begin{array}{c}12.34 \\
\pm \\
1.47 \mathrm{~b}\end{array}$ & $\begin{array}{c}13.39 \\
\pm \\
2.1^{\mathrm{c}}\end{array}$ & $\begin{array}{c}13.79 \\
\pm \\
2.09 \mathrm{c}\end{array}$ & $\begin{array}{c}14.87 \\
\pm \\
2.87 \mathrm{c}\end{array}$ \\
\hline
\end{tabular}

Each value represents Mean $\pm S D$ of replicates $(n=5)$, values represent with the same superscript letter along the column are not significantly different $(P<0.05)$ 


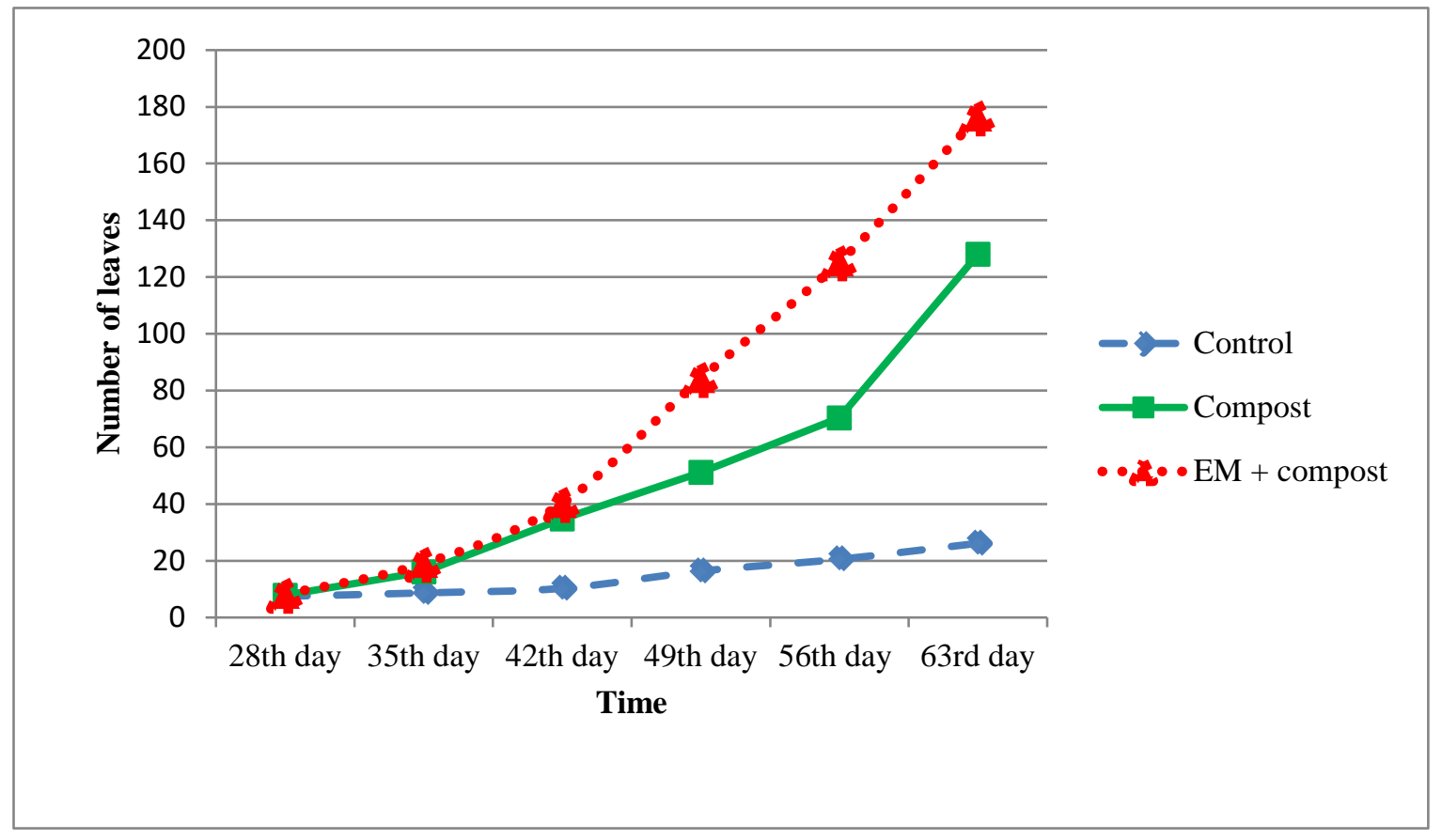

Fig. 2. Number of leaves per plant

\section{Number of branches per plant}

The mean number of branches increased with cultivation time of chilli (Figure 3 ). At $4^{\text {th }}$ day, $56^{\text {th }}$ day. $63^{\text {rd }}$ day, $\mathrm{EM}+$ compost treated crops showed significantly highest number of branches per plant compare to other treatments. At $63^{\text {rd }}$ day the highest number of branches per plant was observed in EM + compost treated crops (44.67) while lowest was observed in control (3.067) (Fig. 3).

Very less number of branches was observed for control compared to other treatments. According to Berova et al. (2010) and Rorie et al. (2011), the plants required high macronutrients (Nitrogen-N) during the initial growth, therefore the plants that gain high supply of $\mathrm{N}$ would increase the vegetative growth. The insufficient $\mathrm{N}$ availability could be the reason for less number of branches in control at $49^{\text {th }}$ day. In the study area, there were no cultivation and fertilizer application observed before and the soil fertility may be very low to encourage initial growth and branching without application of any fertilizer.

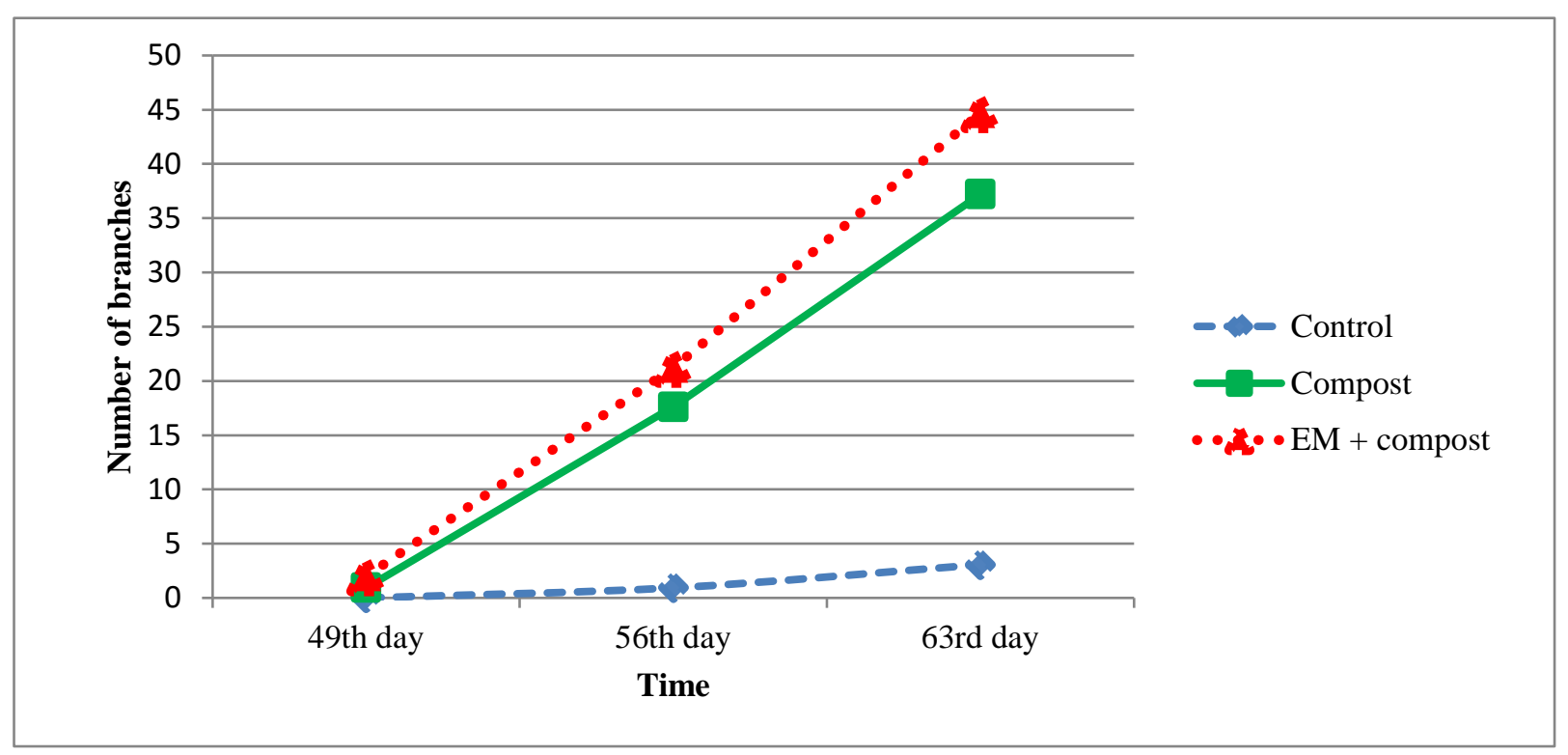

Fig. 3. Number of branches per plant 
Table 2. Number of flowers and pods per plant and Mean length and width of chilli pods

\begin{tabular}{|c|c|c|c|c|c|}
\hline Treatment & $\begin{array}{l}\text { Number } \\
\text { of flowers } \\
\pm \text { SD }\end{array}$ & $\begin{array}{l}\text { Number } \\
\text { of chilli } \\
\text { pods } \\
\pm \text { SD }\end{array}$ & $\begin{array}{l}\text { Length }(\mathrm{cm}) \\
\pm \mathrm{SD}\end{array}$ & $\begin{array}{l}\text { Width(cm) } \\
\pm \text { SD }\end{array}$ & $\begin{array}{l}\text { Weight of chilli } \\
\text { pods }(g) \\
\pm S D\end{array}$ \\
\hline EM+ compost & $15.47 \pm 2.99 a$ & $10.60 \pm 2.50^{a}$ & $5.95 \pm 0.31^{a}$ & $1.08 \pm 0.09 a$ & $29.93 \pm 9.36^{a}$ \\
\hline Compost & $13.20 \pm 2.46^{b}$ & $8.27 \pm 1.98^{b}$ & $5.82 \pm 0.23^{a}$ & $1.01 \pm 0.08^{a}$ & $24.50 \pm 7.40^{\mathrm{a}}$ \\
\hline Control & $4.13 \pm 2.10^{c}$ & $1.47 \pm 0.52^{c}$ & $4.92 \pm 0.35^{b}$ & $0.81 \pm 0.09 \mathrm{~b}$ & $1.97 \pm 0.71^{\mathrm{b}}$ \\
\hline
\end{tabular}

Each value represents Mean $\pm S D$ of replicates $(n=5)$, values represent with the same superscript letter along the column are not significantly different $(P<0.05)$.

\section{Number of flowers per plant}

Generally, continuous flowering of the chilli crops starts 60-90 days after sowing. (Khaing et al., 2016). Highest mean number of flowers was observed in EM + compost treated crops which were significantly different compared to control and compost treated (Table 2). This may be due to application of EM enhance decomposing of organic fertilizer and nutrient uptake quickly compared to other treatments. The study by Ahmad et al. (1993) proved that EM enhanced root growth in maize and rice by solubilizing the organic phosphorus in soil and increased the yield.

\section{Number of chili pods per plant}

Mean number of chili pods per crop was showed significant differences in respect to different treatments at first harvest (Table 2). EM application increased the pod production in Chili. Similar results were observed in other study conducted by Khaing et al. (2016) concluded, that application of EM fertilizer was enhanced fruit production in chilli. Lee (1994) and Chowdhury et al. (1994) reported a much greater effect of EM on the yield of chilli and pepper. According to Moraditochaee et al. (2011), nitrogen application could fulfill the requirement for $\mathrm{N}$ and increase number of fruits and total yield. And the most significant impact of EM was seen when it was applied with gliricidia leaves; gliricidia has a low C: N ratio (Sangakkara, 1990).

\section{Length and width of chilli pods}

Mean length and width of a chilli pods from EM + compost treated and compost treated crops were significantly different from control $(\mathrm{P}=0.000)$. There was no significant difference observed between EM + compost treated crops and compost treated crops (Table 2).

\section{Weight of total chilli pods per crop at first harvest}

Mean weight of chilli pods per crop for different treatments were significantly different from control $(\mathrm{P}=0.000)$. Weight of total chilli pods at first harvest was not significantly different in EM + compost treated crops and compost treated crops. Control showed least weight of production (Table 2). The positive responses of EM on yield was also observed in the study conducted by Karunarathna and Seran (2016) which showed that application of EM with cattle manure increased the cumulative fresh weight of pods compare to inorganic fertilizer application.

\section{Conclusion}

This study was conducted to evaluate the efficacy of homemade EM solution to promote organic farming system. Mean 
height of the chilli crops, mean number of leaves per plant, mean number of branches per plant, mean number of flowers and number of chilli pods per plant were significantly increased in EM+ compost treated crops compared to control. But there were no significant differences observed in length and width, weight of the chilli pods per plant.

Overall the present study suggests that the growth, yield parameters of the chilli crops increased in compost treated with Effective Microorganisms compared to compost only and control.

However, adoption of the technology of EM and commercialization will ensure the sustainable basis ecofriendly approach in agriculture thus lead to cleaner environment for humankind and its future generations.

\section{References}

Ahmad., Hussain, R.T., Jilani, G., Shahid, S.A., Naheed Akhtar, S., and Abbas, M.A. (1993).Use of effective microorganisms for sustainable crop production in Pakistan. Proceedings $2^{\text {nd }}$ Conference on Effective Microorganisms (EM). November 17-19, Saraburi Thailand, 15-27.

Arshad, M., and Frankenberger, W. T. (1992). Microbial production of plant growth regulators in Soil Microbial Ecology, ed. FB Metting Jr. New York, Marcel Dekker, 307-348.

Berova, M., Karanatsidis, G., Sapundzhieva, K., and Nikolova, V. (2010). Effect of organic fertilization on growth and yield of pepper plants (Capsicum annuum L). Folia Horticulture, 22: 3-7.

Chowdhury, A. R., Hossain, M. M., Mia, M. S., Karim, A. J. M. S., Haider, J., Bhuiyan, N. I., and Saifuddin, Kh. (1994). Effect of organic amendments and EM on productivity of different crops in Bangladesh. In Parr, J. F., Hornick, S. B., and Simpson, M. E. Proceedings of the Second International Conference on Kyusei Nature Farming. U.S. Department of Agriculture, Washington, D.C., USA, 115163.

Higa, T., and Kanal, A. (1998).An Earth Saving Revolution II: EM- Amazing Application to Agricultural, Environmental and Medical problems, first edition, Sunmark Publishing Incorporated., Sunmark Building., 1-32-13, Takadanobaba, Shinjuku-ku, Tokyo, Japan, 367.

Igedioh, S.O. (1991).Effects of agricultural pesticides on humans, animals and higher plants in developing countries. Archives of Environmental Health: An International Journal, 46 (4): 218-224.

Karunarathna, B., and Seran, T.H. (2016). Field evaluation of cattle manure along with effective microorganisms on growth and yield of capsicum (capsicum annum L.). International

Journal of Advanced Research and Review, 1: 10-18.

Khaing, M. M., and Kyu, K. (2016). Effects of priming tests and fertilizer applications on germination, growth and yields of chilli (Capsicum annum L), Hinthada University Research Journal, 7: 97-105.

Lee, K.H. (1994). Effect of organic amendments and EM on the growth and yield of crops and on soil properties. In Parr, J. F., Hornick, S. B., and Simpson, M. E. Proceedings of the Second International Conference on Kyusei Nature Farming. U.S. Department of Agriculture, Washington, D.C., USA. October 7-11, 1991, 142-147.

Moraditochaee, M., Bozorgi, H. R., and Halajisani, N. (2011).Effects of vermicompost application and nitrogen fertilizer rates on fruit yield and several attributes of eggplant (Solanum melongenal 
L.) in Iran. Journal of World Applied Sciences, 15 (2):174-178.

Pendleton, J. W., and Lawson, T. L. (1989). Climatic variability and sustainability of crop yields in the humid tropics.In Climate and Food Security. International Rice Research Institute, Los Baños, Philippines, 57-58.

Rorie, R.L., Purcell, L.C., Mozaffari, M., Karcher, D.E., King, C.A., Marsh, M.C., and Longer, D.E. (2011). Association of "Greenness" in corn with yield and leaf nitrogen concentration. Agronomy Journal, 103 (2): 529-535.

Sangakkara, U.R. (1990). Research on the technology of Effective Microorganisms in Sri Lanka. Department of Crop Science University of Peradeniya, Peradeniya, Sri Lanka. http:/ / infrc.or.jp/english/KNF_Data_Bas e_Web/3rd_Conf_S_5_3.html

Sangakkara, U.R. (1998). Effect of EM on Vegetable Production in Sri Lanka: An Economic Analysis. Department of Crop Science, University of Peradeniya, Peradeniya, Sri Lanka. Retrieved from https://www.researchgate.net

Asia-Pacific Natural Agriculture, (1995). EM Application Manual for APNAN Countries. Asia-Pacific Natural Agriculture Network, Bangkok, Thailand. https://www.researchgate.net

Takash, K., Masaki, S., Shoji, K., Masanobu, S., Hiroyasu, O., Aki, F., and Somlaki, P. (1999).Kyusei Nature Farming and the Technology of Effective Microorganisms: Guideline for practical use, Revised Edition, Published by APNAN BangkokThailand and INFRC Atami-Japan. 